\title{
FABRICATION AND TEST OF A TRACTOR-FRONT-MOUNTED TWO-ROW SUGARCANE HARVESTER
}

\author{
Abdallah M. Zein El-den ${ }^{1}$, Saad F. Ahmed ${ }^{1}$, Waleed M. Hanafy ${ }^{2}$, Abdallah E. Elwakeel ${ }^{3 \&^{*}}$ \\ ${ }^{1}$ Prof., of Ag. Eng., Fac. of Ag., Alexandria U., Alexandria, Alshatby, Egypt. \\ ${ }^{2}$ Assist. Prof., of Ag. Eng., Fac. of Ag., Aswan U., Aswan, Egypt. \\ ${ }^{3}$ Assist. Lect., of Ag. Eng., Fac. of Ag., Aswan U. Aswan, Egypt. \\ * abdallah_elshawadfy@agr.aswu.edu.eg
}

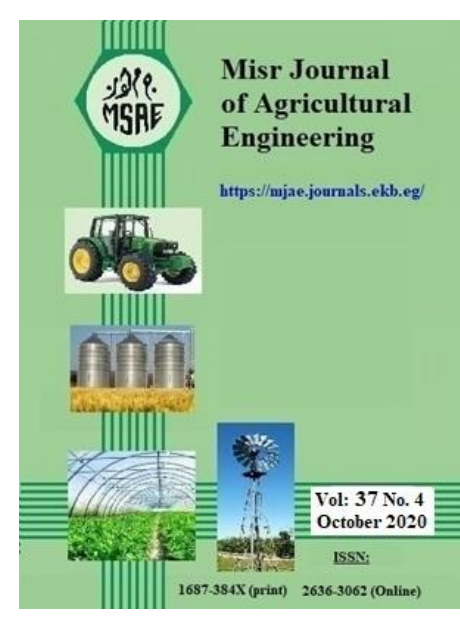

() Misr J. Ag. Eng. (MJAE)

\section{Keywords:}

Sugarcane Harvesting

Systems, Mechanized

Systems, Sugar Cane

Combine, Tractor Mounted

Cutters

\section{ABSTRACT}

A tractor-front mounted sugarcane harvester was fabricated and tested. The machine parts were designed using "SolidWorks" software. The machine was then manufacturing and constructed by using the low cost material available in local market. Main components of this machine are machine frame, cutter head, power transmission system, and power supply. Results of the tests showed that the effective field capacity ranged from 1.16 to 1.3 $\mathrm{fed} / \mathrm{h}$, and increased with an increase in row spacing and forward speed. In the high crop density fields, the cutter head efficiency averaged $100 \%$. It, however, increased with a decrease in cutting height and also, increased with an increase in row spacing and number of knives. The throughput capacity increased from 42.9 to $79.02 \mathrm{t} / \mathrm{h}$ as the row spacing increased from 71 to $88.75 \mathrm{~cm}$ and the maximum total operating costs are $120 \mathrm{EGP} / \mathrm{h}$ (98.5 and 92.3 $E G P / F e d)$ depending on the power requirements.

\section{INTRODUCTION}

$\mathrm{S}$ ince about 4 decades the sugar cane production is fully mechanized in several countries around the world. Commercially manufacturing of mechanical sugar cane harvesters have started in Hawaii, Australia, Southern USA, and Japan. Countries which have large areas of sugar cane such as Brazil, India, Cuba, South Africa, and China may have large agricultural sectors that economically apply full mechanization. Other medium sectors that apply semi-mechanization and small size farms that still harvest sugar cane manually. Except for Egypt, no successful sugar cane harvester has been developed so far. Several trails have been done to locally demonstrate imported sugar cane harvesters. The demonstrated machines were not accepted by the local farmers because of poor performance represented in poor cost-saving, poor labor-saving and poor time-saving. Therefore, no advantages of the demonstrated sugar cane harvesters' performance attract the farmers to use them. Other trails to develop and test local designs of sugar cane cutter harvesters through graduate students' research programs have not been succeeded. (Abdel-mawla, 2014). Sugar cane plantation is concentrated in the area of Upper Egypt. The total amount of cane cultivated in Upper Egypt is about 16 million tons per year (303,682 feddan) with average production $48 \mathrm{t} / \mathrm{Fed}$. The crop is harvested from December- May 
at an average age of 12 months. There are eight sugar cane producing factories in Egypt, from El Menia to Aswan as follows: (El Menia; Abou Korkas mill - Sohag; Gerga mill - Qena; Nagaa Hamadi, Deshna, and Kous mills - Luxor; Armant mill - Aswan; Edfu and Komombo Mills) (Hamada, 2011). Harvesting is one of the key operations responslble for the increase in sugar cane production cost. Hence mechanization of sugar cane harvesting is essential not only for reducing the production cost but also for reducing drudgery involved in manual harvesting operations, and also to ensure quality produce. (Bastian and Shridar, 2014). The manually cutting is a very laborintensive, the workers usually become fatigued after a few hours and they need frequent pauses for rest. (Rohit and Sharad, 2015). Due to the high levels of sun exposure, Precautions need to be taken to limit or protect the workers because it can result in various types of skin cancer conditions (Siddaling and Ravaikiran, 2015). Due to wages increasing and the unavailability of labor to cut sugar cane by hand, the South African Industry considered various options for mechanical sugar cane harvesting (Debeer, 1974).

\section{Objectives of this study are to:}

1- Study the physical and mechanical properties of sugar cane.

2- Design and construction of a prototype sugar cane harvester suitable for smallholdings under Egyptian conditions.

3- Test and evaluate the performance of the machine in the field.

4- Precede an economical evaluation of the machine.

\section{MATERIALS AND METHODS}

To achieve the objectives proposed for the current study, an experimental sugar cane harvester was designed and manufactured at a local workshop in El-Minya governorate - El-Minya, Egypt, 2017. This experimental unit was designed to cut two rows of sugar cane and windrow them in one row below the tractor. The experimental unit was designed to be compatible with a wide range of row spacing, row height, and tractor types.

\section{Description of the experimental sugar cane harvester:}

The entire experimental sugar cane harvester was subjected to standard design methodology. The sugar cane harvester consists of four main parts; machine frame, cutter head, transmission system, and power supply and hydraulic system, as shown in Fig. 1 and 2.

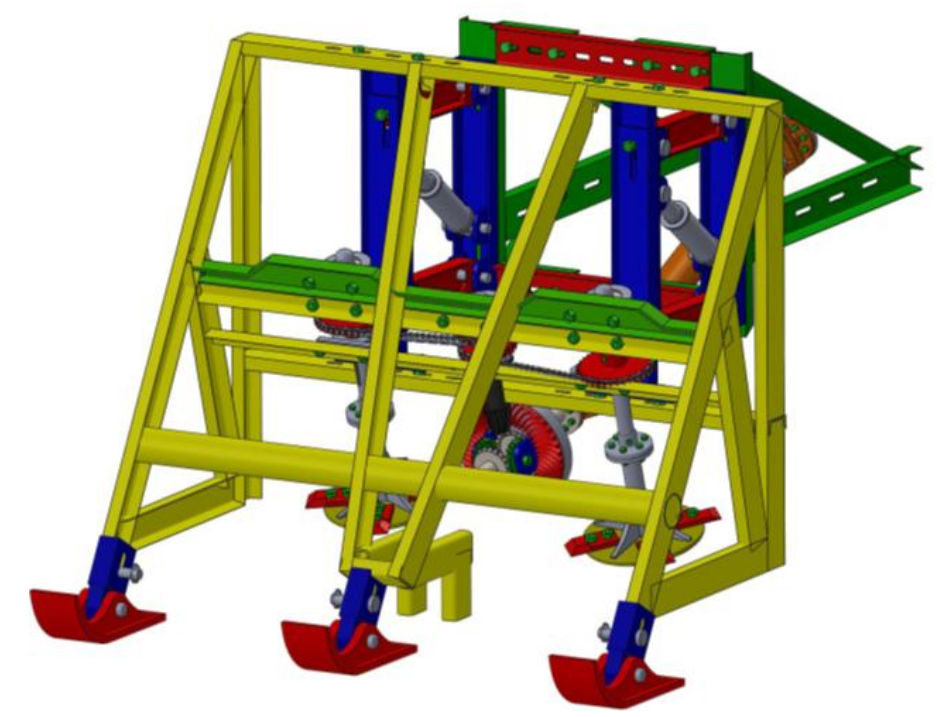

Figure 1: Isometric view of the proposed machine. 


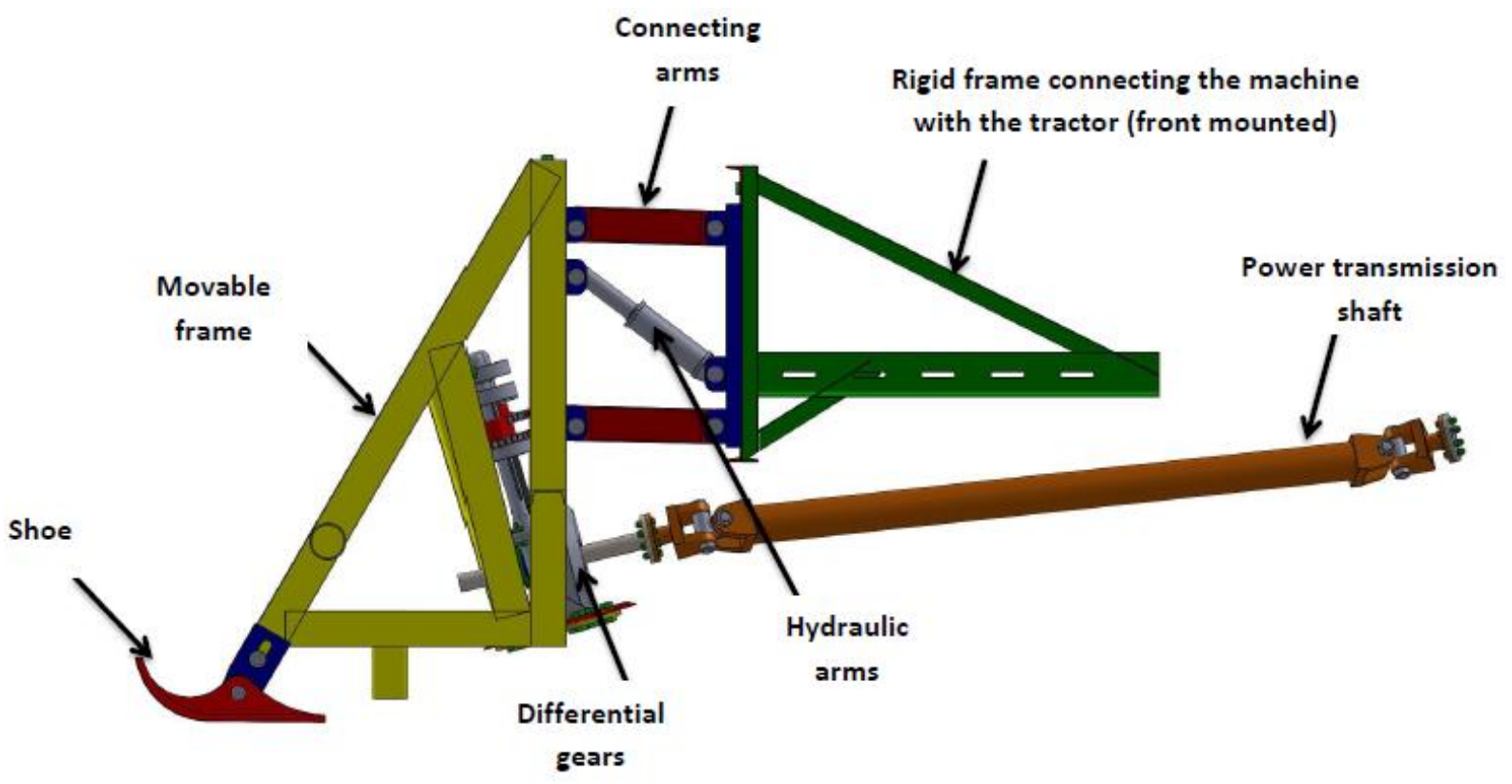

Figure 2: Side view of the proposed machine designed by SolidWorks program.

1.1.Machine frame: The machine frame consists of movable working parts and rigid parts and connecting parts, as shown in Figs 3 and 4.

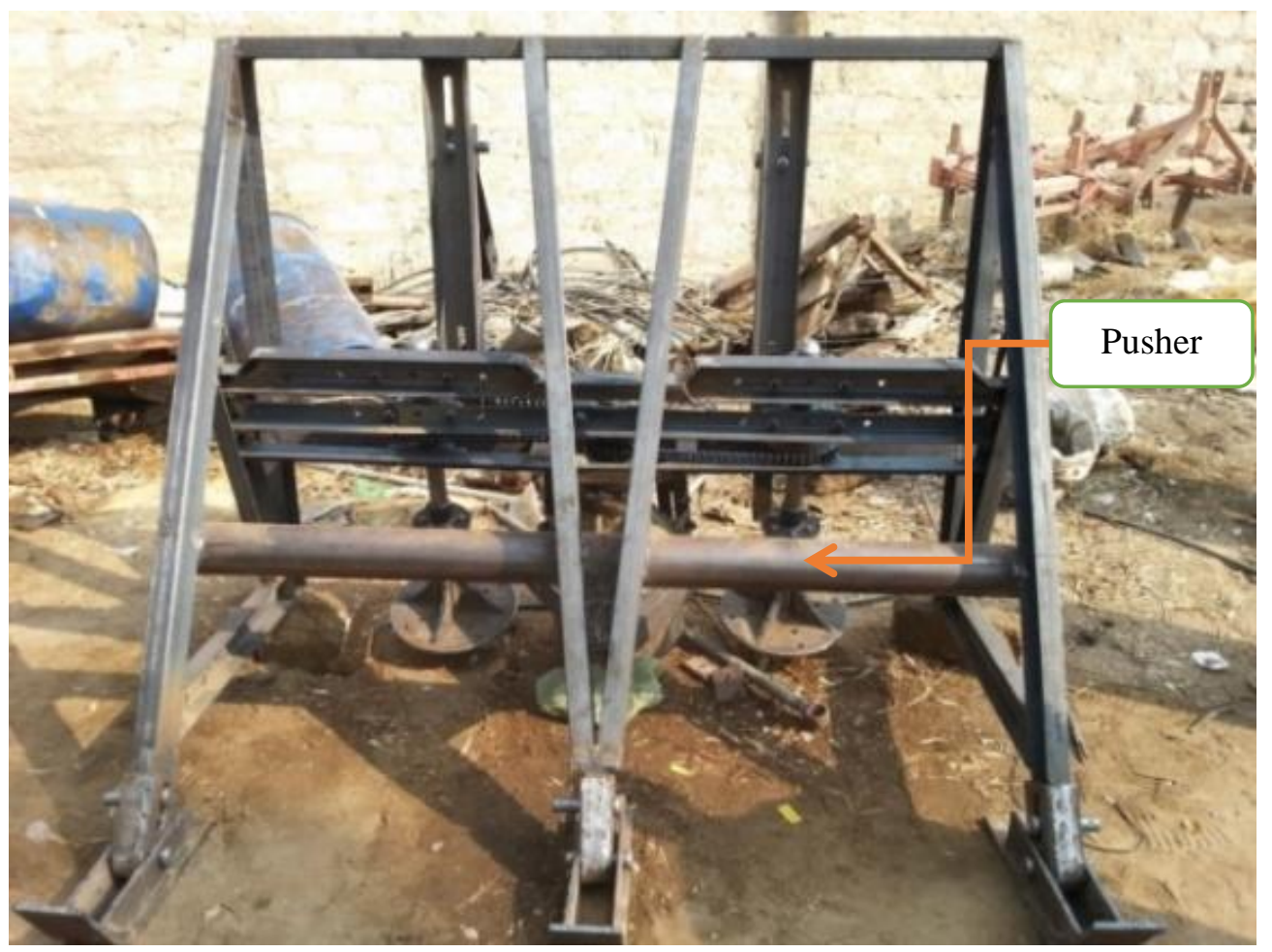

Figure 3: Elevation view of the purposed machine.

\subsubsection{Movable working parts:}

The movable frame support and carry the cutter head and power transmission system, as shown in Fig. 5. The movable frame slips on the soil surface using three articulated shoes to suit the soil surface. The movable frame was constructed out of channel bars ( $4 \mathrm{in} * 7.2 \mathrm{lb}$ [100 mm*10.8 $\mathrm{kg}])$ and angle bars $(2 * 2 * 0.125$ in [51*51*3.2 mm]) and was covered with steel sheets $3 \mathrm{~mm}$ thick. The movable frame dimensions are $140 \mathrm{~cm}$ height, $80 \mathrm{~cm}$ length, and $180 \mathrm{~cm}$ width. 


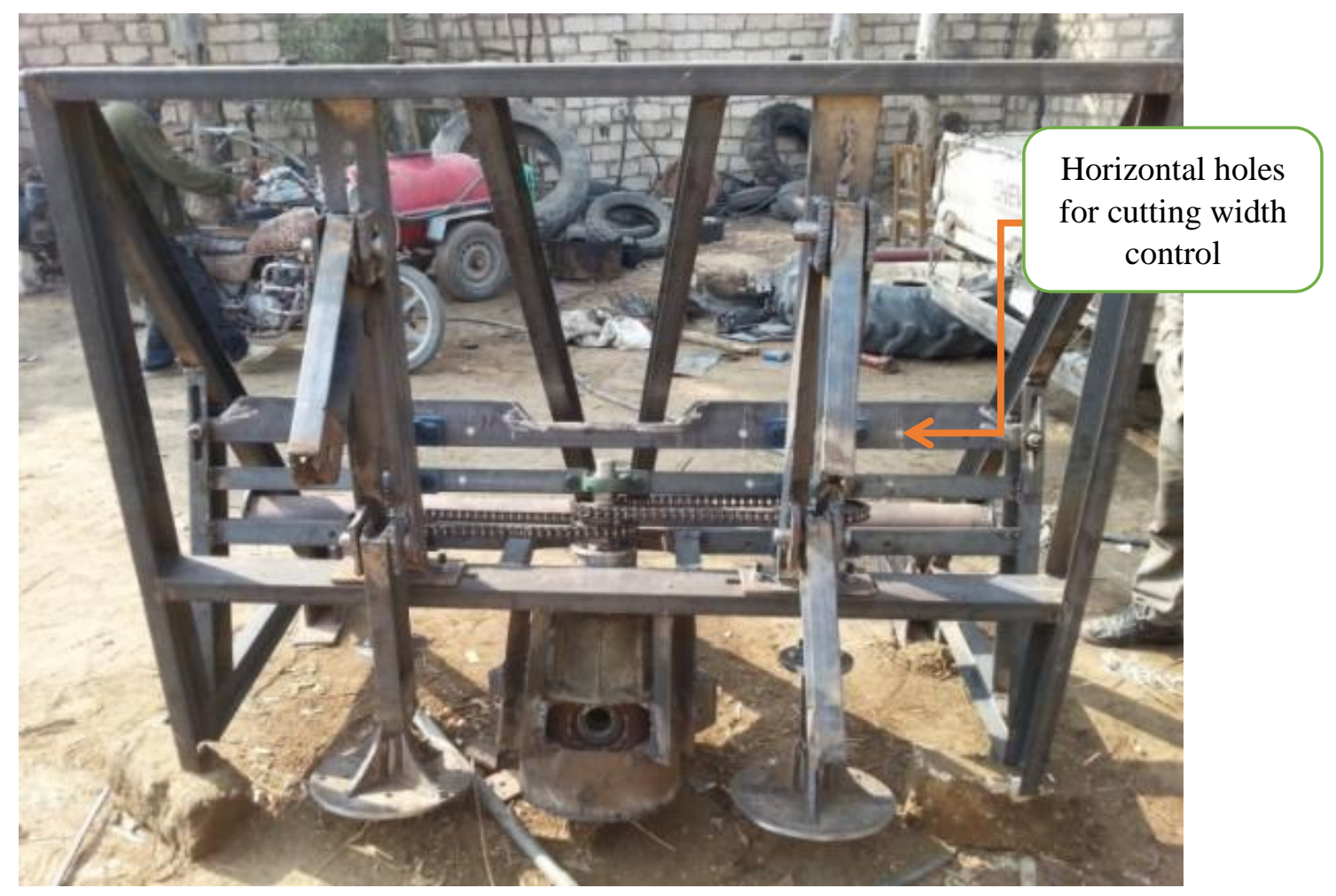

Figure 4: Rear view of the machine prototype.
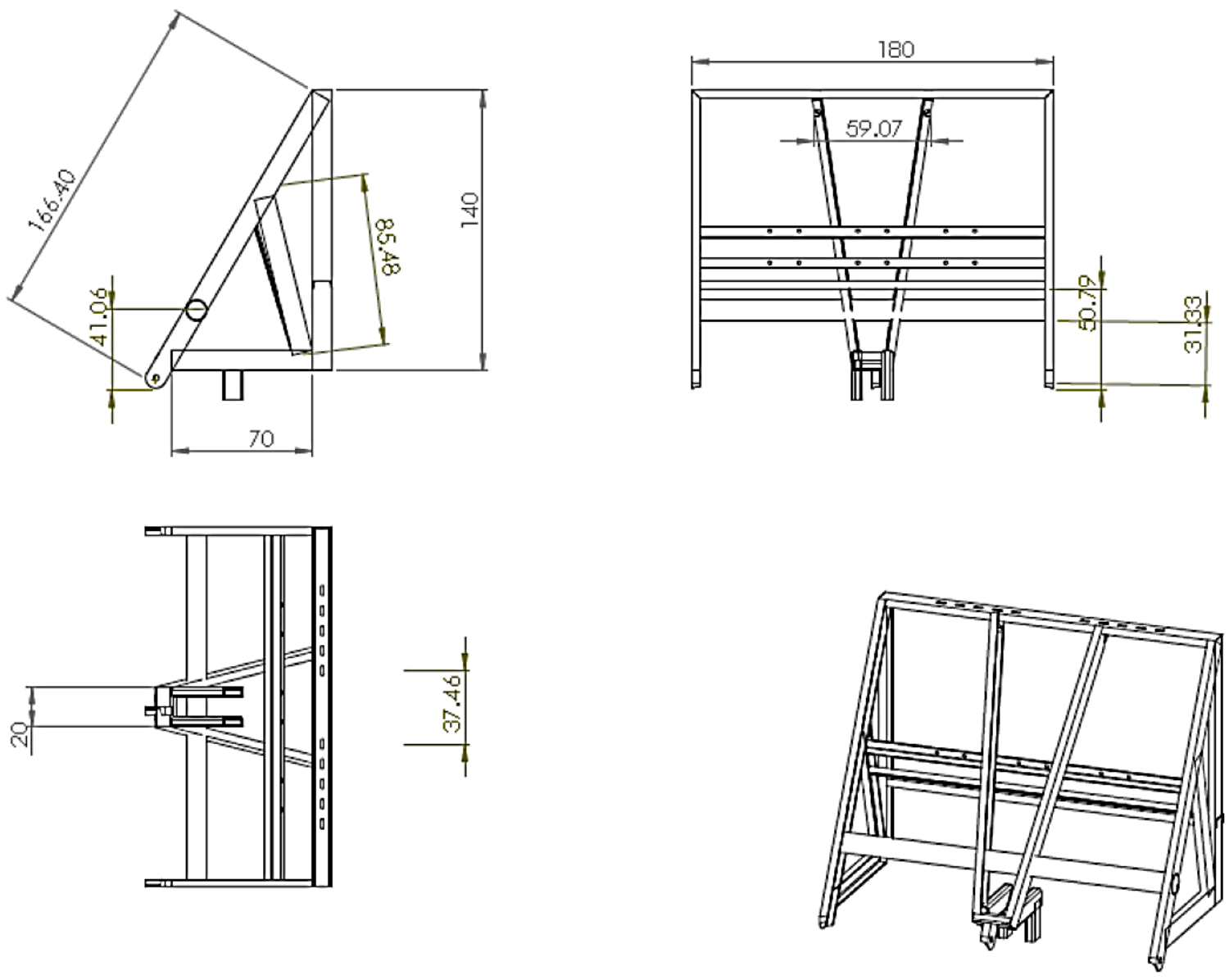

Figure 5: Assembly and detailed views of the machine frame. 
Also, the removable frame has the pusher that used for pushing the sugar cane stalks forward by $75^{\circ}$ in order to support the stalks being cut as shown in fig. (3), It mounted and welded on the removable frame front and was designed at $45 \mathrm{~cm}$ height from the lower member of the removable frame. The rigid frame was designed and constructed out of Round steel $4 * 0.125$ in [101.6*3.2 mm] as shown in Figs 6 and 7. The cutting width or the operating width of the machine can be controlled by moving the knives head horizontally through pre-prepared horizontal holes on the horizontal bar as shown in the fig. (4).
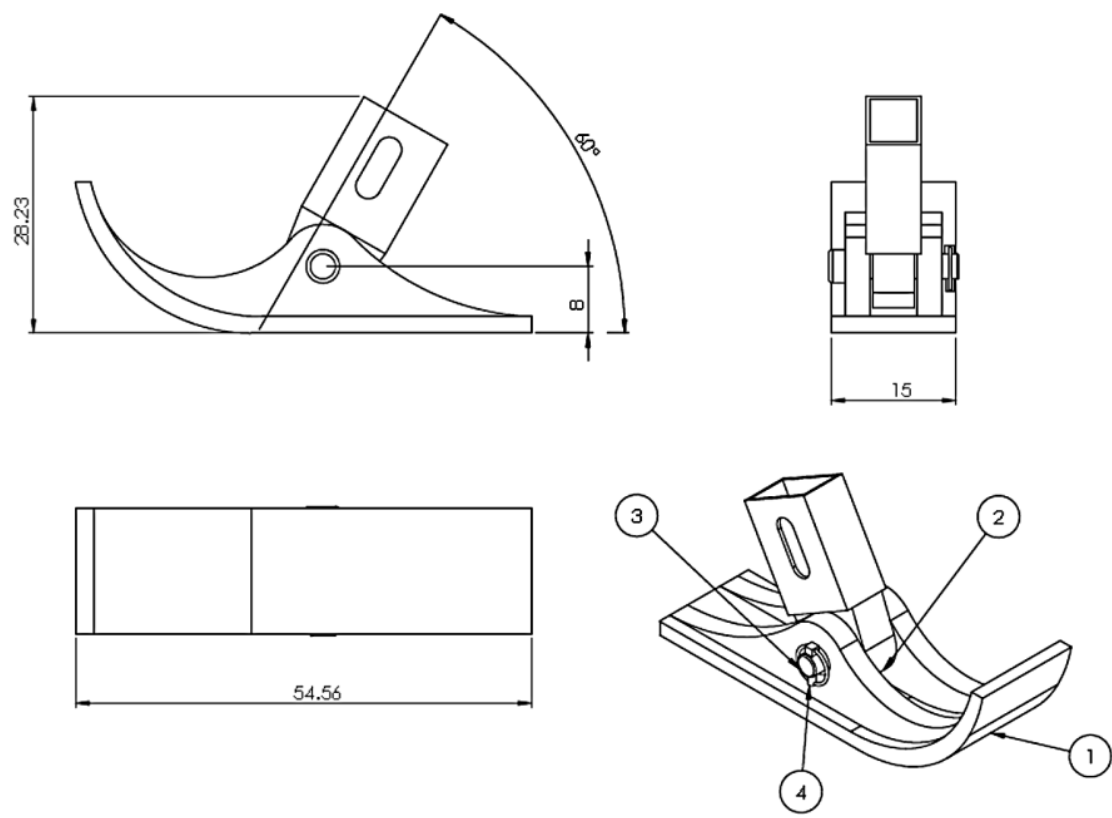

Figure 6: Assembly and detailed views of shoe showing the main dimensions.
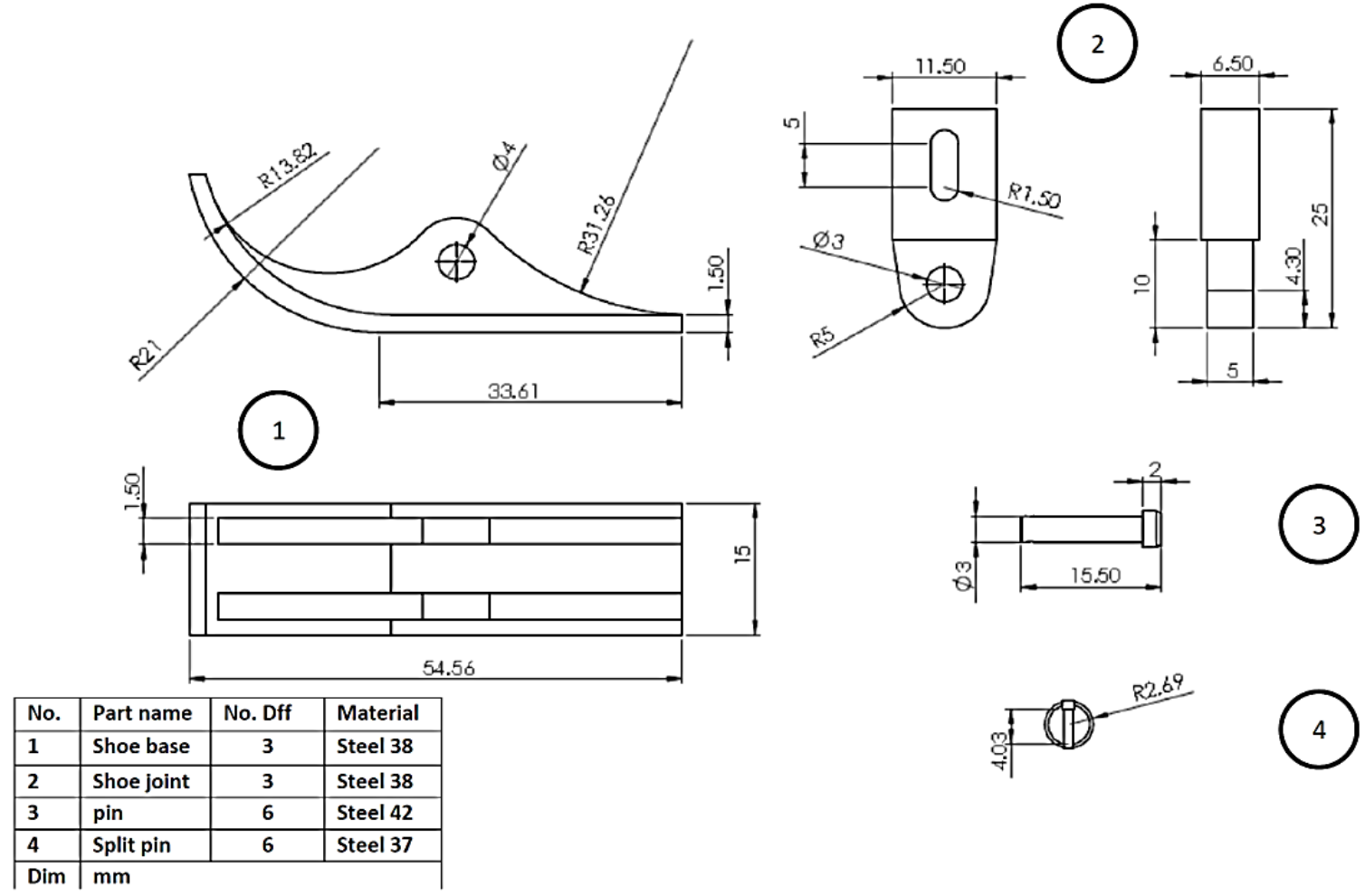

Figure 7: Detailed drawing of the shoe components. 


\subsubsection{The rigid frame and connecting parts:}

The rigid frame was fixed with the tractor chassis by eight bolts M16 at each side and designed to compatible with a wide range of tractor types, as shown in Figs $8 \mathrm{~m}$ and 9. The rigid frame was designed and constructed out of channel bars (4 in *7.2 lb [100 mm*10.8 kg]) and angle bars $(2 * 2 * 0.125$ in $[51 * 51 * 3.2 \mathrm{~mm}])$. The connecting part was designed as a connecting point between the movable and fixed parts by eight bolts M16. The Connecting part consists of four steel arms made of channel bars (4 in *7.2 lb [100 mm*10.8 kg])

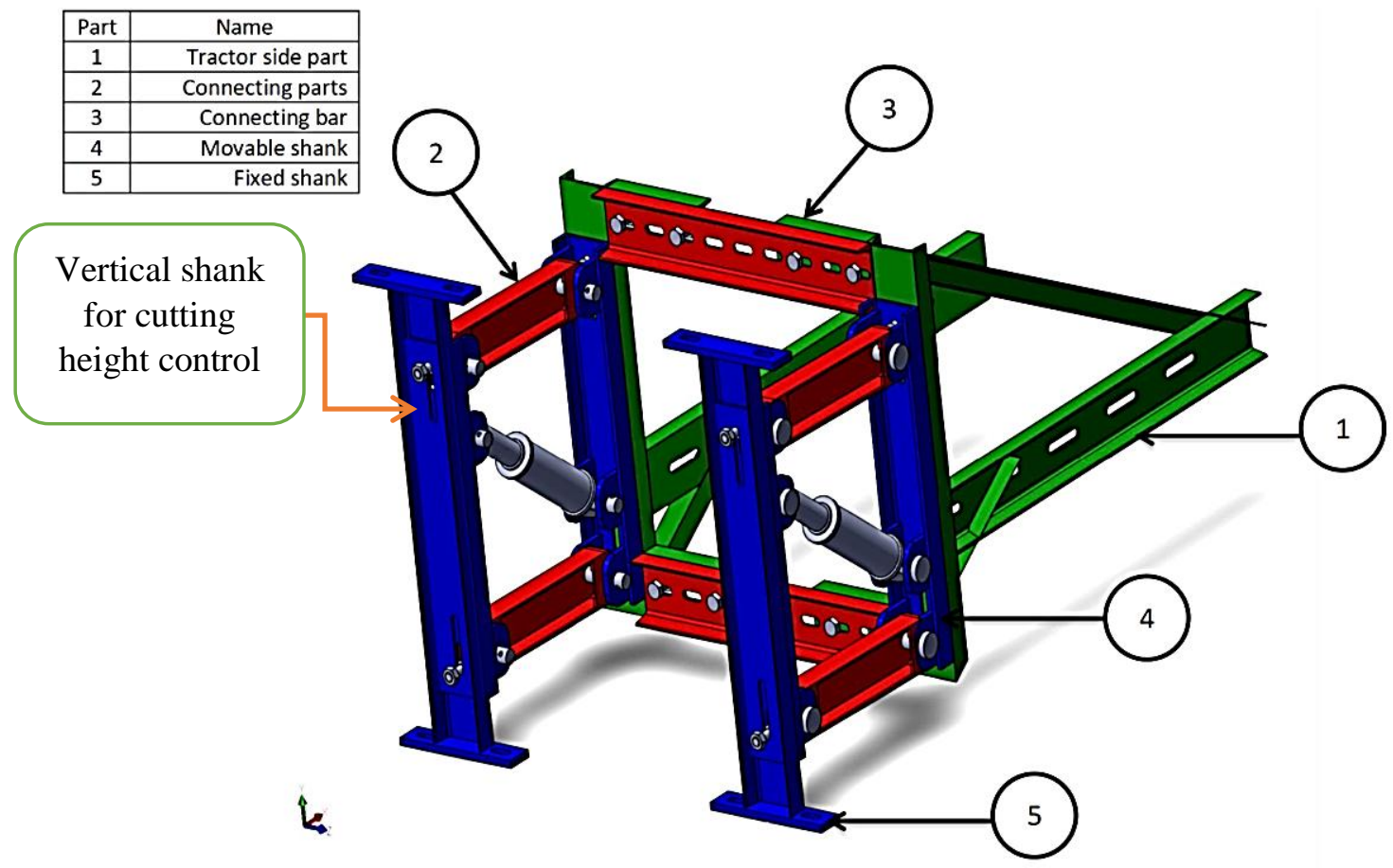

Figure 8: Isometric view of the rigid frame and connecting parts.

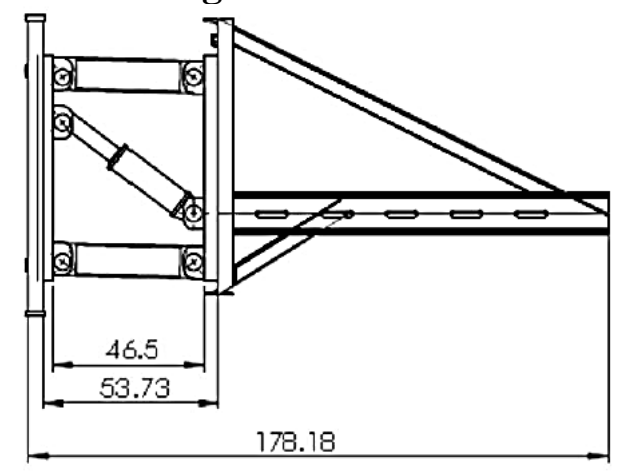

Elevation

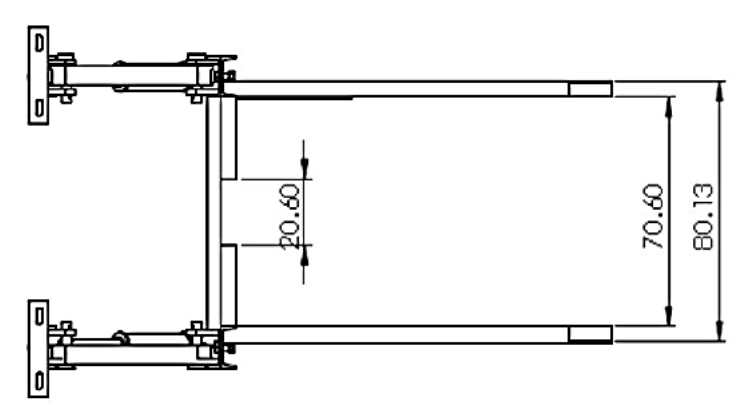

Plan

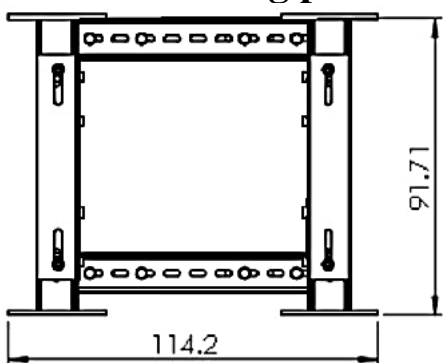

Side view

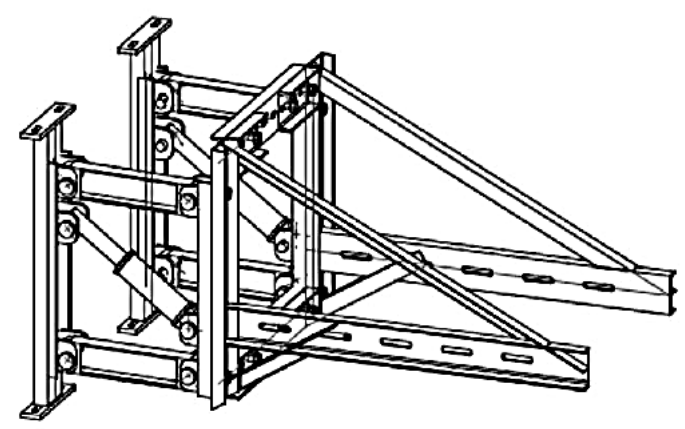

Assembly view

Figure 9: Assembly views of rigid part and connecting parts. 


\subsection{The cutter head:}

The cutter head unit is mounted down on the movable frame. It consists of two horizontal cutting discs mounted on vertical drive shafts, as shown in Fig. 10; each disc is fitted with four cutting blades. The cutter head height can be adjusted by three different ways as follow, first way by raising or lowering the front part of the machine by hydraulic cylinder as shown in fig. (8), second way by raising or lowering the cutter heads' bar within $20 \mathrm{~cm}$ and third way by raising as shown in figs (11 and 12) or lowering the fixed shank of the rigid frame as shown in figure (8). The cutter head is consisted of three main parts; cutting blades, round disk, deflector sheets.
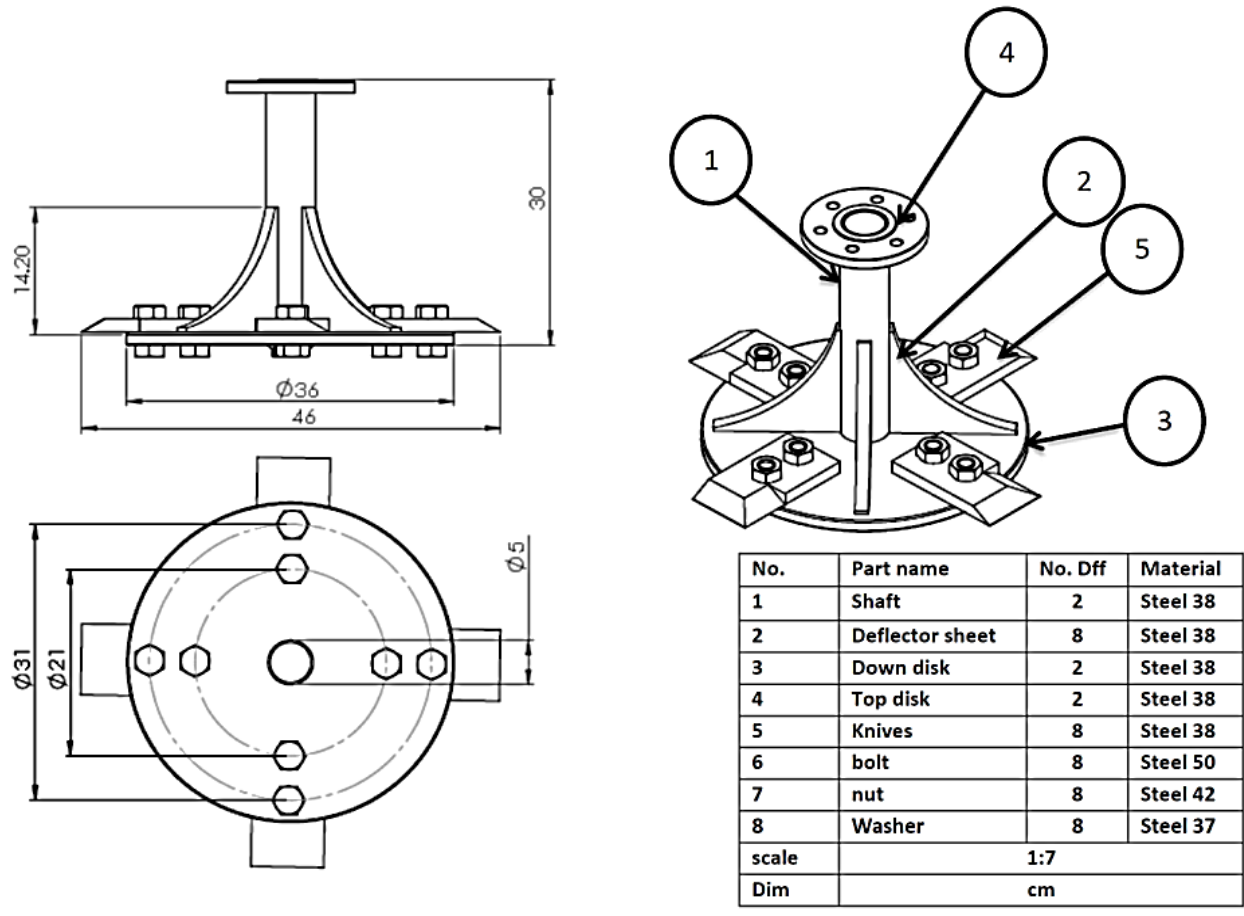

Figure 10: Isometric and detailed views of the cutter head.

\subsection{Power transmission system and power supply:}

\subsubsection{Power transmission system:}

The power transmission system of the experimental sugar cane harvester consisted of four main parts, as shown in Fig. 11; universal joints, shafts, differential gear, chains, and sprockets. It was designed to get a wide range of cutting speeds depending upon the forward speed because the machine takes power from the front axles of the tractor that gives the machine constant speed ratio at any forward speed and the front axle clutch of the tractor separates movement from the knives when safety limits are crossed. Also, we can change the speed ratio by changing the reduction ratio between chain and sprockets that ratio is approximately $3.5: 1$ at a speed range from $1 \mathrm{~km} / \mathrm{h}$ to $5 \mathrm{~km} / \mathrm{h}$.

\subsubsection{Power supply:}

The experimental sugar cane harvester was front-mounted and drives by agriculture tractor (Belarus MTZ-82).

\subsection{Hydraulic system:}

The hydraulic system was used for raising or lowering the movable frame of the experimental machine. There are two options can be use, the first. We can use two hydraulic cylinders (40 $\mathrm{cm}$ close length, $70 \mathrm{~cm}$ open length and $500 \mathrm{~kg}$ lifting weight) or We can use only one hydraulic 
cylinder (70 cm close length, $100 \mathrm{~cm}$ open length and $1000 \mathrm{~kg}$ lifting weight). The hydraulic cylinder was connected to the tractor-front hydraulic valves through two hydraulic lines. So, they could be raised or lowered by the tractor-hydraulic controller.

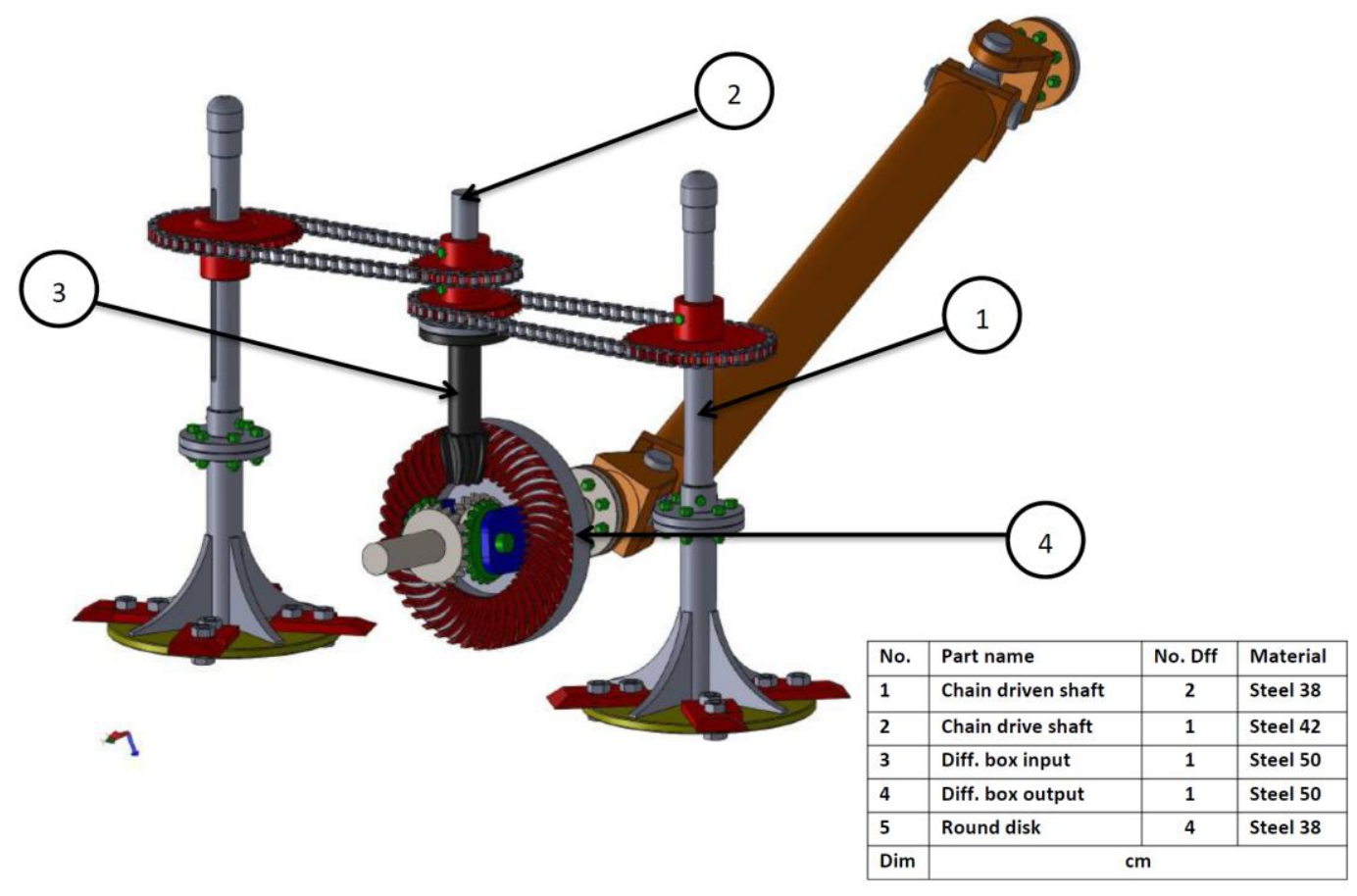

Figure 11: Isometric view shows the main components of the power transmission system.

Internal linear groove for cutting height control

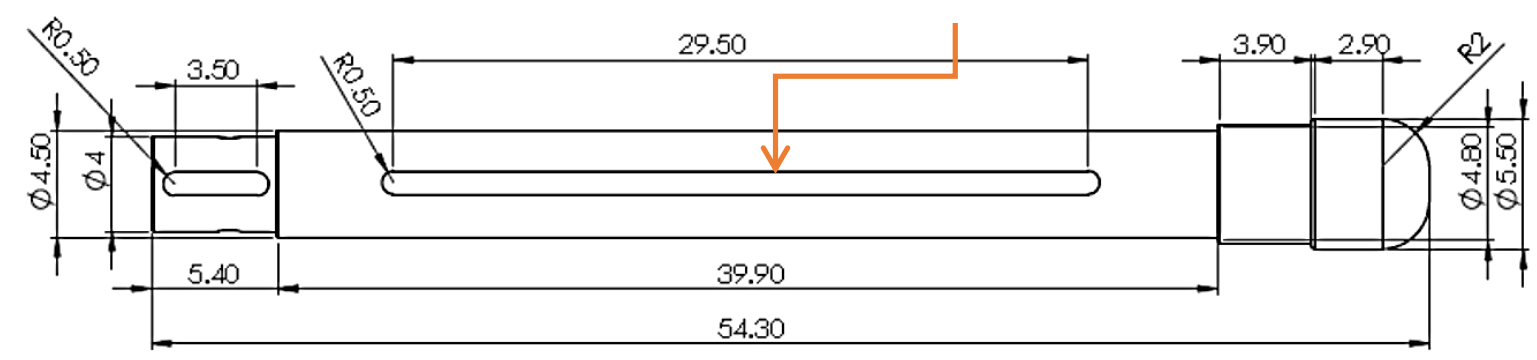

Figure 12: detailed view of chain driven shaft shows linear groove.

\subsection{Performance Tests of the machine prototype:}

The prototype sugar cane harvester was tested in the Research Center and Agriculture Researches - El-Minia - Egypt. Tests were carried out to evaluate the machine performance in terms of effective field capacity, field efficiency, material capacity, cutter head efficiency, fuel consumption, and power requirements.

\section{Experimental variables:}

Field tests were conducted to evaluate the performance of the harvesting unit by studying the following variables:

1. Forward speed $3,3.5,4.5$ and $5 \mathrm{~km} / \mathrm{h}$.

2. Row spacing 70, 80 and $90 \mathrm{~cm}$ (Stalk diameter 2.5 , 3and $3.5 \mathrm{~cm}$ respectively).

3. Cutting height at ground level, 2 and $4 \mathrm{~cm}$.

4. The number of knives 2 and 4.

5. Knives velocity at constant speed ratio with the forward speed $=20: 1$. 


\subsubsection{Effective field capacity:}

The effective field capacity of the machine was calculated according to the following formula:

$$
F_{C}=\frac{A p}{T k}
$$

Where, AP = area of the field portion, Fed.

$\mathrm{T}_{\mathrm{k}}=$ time consumed to complete the harvesting area of the sugar cane crop, $\mathrm{h}$.

\subsubsection{Field efficiency:}

Field efficiency of the machine was calculated according to the following formula:

$$
F e=\frac{4.2 \times F C}{S \times W}
$$

Where, $\mathrm{S}=$ speed of operations, $\mathrm{km} / \mathrm{h}$.

$\mathrm{W}=$ operational width of equipment, $\mathrm{m}$.

$\mathrm{Mc}=$ material capacity, $\mathrm{t} / \mathrm{h}$

\subsubsection{Machine productivity:}

The throughput capacity of the machine defined as the mass of material handled by the equipment per hour was calculated according to the following formula:

$$
M c=F c \times Y
$$

Where, Fc = effective field capacity, Fed/h.

$\mathrm{Y}=$ sugar cane yield, $\mathrm{t} / \mathrm{Fed}$.

\subsubsection{Cutter head efficiency:}

The cutter head efficiency was determined by selecting one hundred sugarcane stems from the field and harvesting them using the machine. The harvested stalks were then separated into those that were completely cut at the base, those that were uprooted and those that were not cut. The cutter head efficiency was calculated according to the following formula:

$$
B c e=\frac{N c}{N t} \times 100
$$

Where, $\mathrm{Nc}=$ number of stems completely cut.

$\mathrm{Nt}=$ total number of sugar cane stems.

\subsubsection{Fuel consumption:}

A volume of fuel consumed $\left(\mathrm{cm}^{3}\right)$ was measured during each test run at cutting load. Consumption time for each test was measured and volumetric fuel consumption rate was calculated for each load as follow:

$$
\mathrm{F}_{\mathrm{C}}=(\mathrm{V} * 3600) /(\mathrm{t} * 1000)
$$

Where, $\mathrm{F}_{\mathrm{C}}=$ volumetric fuel consumption, $1 / \mathrm{h}$

$\mathrm{V}=$ volume of consumed fuel, $\mathrm{cm}^{3}$

$\mathrm{t}=$ time of running the test, $\mathrm{s}$.

\subsubsection{Power requirements:}

The power requirements for harvesting sugar cane stalks were calculated according to the following formula:

$$
\mathbf{P}=\mathrm{F}_{\mathrm{C}} * \mathrm{CV} * \eta_{\mathrm{th}} / 3600
$$

Where, $\mathrm{P}=$ power requirements, $\mathrm{kW}$. (Brake power)

$\mathrm{F}_{\mathrm{C}}=$ fuel consumption, $\mathrm{kg} / \mathrm{h} . \quad$ [(fuel consumption in $\left.\mathrm{L} / \mathrm{h}\right) \times(\rho$ in $\left.\mathrm{kg} / \mathrm{L})\right]$ 
$\eta_{\mathrm{th}}=$ thermal efficiency.

$\mathrm{CV}=$ calorific value of kilogram fuel, $\mathrm{kJ} / \mathrm{kg} \quad[\mathrm{CV}=44800 \mathrm{~kJ} / \mathrm{kg}$ for diesel fuel $]$

$\rho=$ relative density of fuel, $\mathrm{kg} / \mathrm{L} \quad[\rho=0.82 \mathrm{~kg} / \mathrm{l}$ for diesel fuel $]$

\subsection{Cost estimation of owning and operating the proposed machine:}

Formulas developed by the American Society of Agricultural and Biological Engineers (ASABE) are used to calculate costs. All costs are based on buying a new proposed prototype of the sugar cane harvester, owning the machine for 5 years and using it 1200 hours per year (Starting from the beginning of Dec. and normally completed by late in Apr.).

\section{RESULTS AND DISCUSSIONS}

Tests were carried out to evaluate the machine performance in terms of effective field capacity, field efficiency, material capacity, cutter head efficiency, fuel consumption, and power requirements.

\section{Effect of forward speed:}

The proper forward speed required for harvesting sugar cane at the ground level is a very important factor. Four forward speeds were used as 3, 3.5, 4.5 and $5 \mathrm{~km} / \mathrm{h}$ to determine the proper forward speed for harvesting sugar cane stalks from the ground level. The length of each test was $25 \mathrm{~m}$ and was repeated thrice. The proposed fixed parameters to carry out these experiments were: cutting heights $=$ Ground level, 2 , and $4 \mathrm{~cm}$, row spacing $=70,80$, and 90 $\mathrm{cm}$, stalk diameters $=2.5,3$, and $3.5 \mathrm{~cm}$ and No. of knives $=2$, and 4 .

Results indicated that the best appropriate forward speed required for harvesting sugar cane stalks are:

1. For stalk diameter $2.63 \mathrm{~cm}$, row spacing $71 \mathrm{~cm}$, cutting height $0 \mathrm{~cm}$ with both 2 and 4 knives, the proper forward speed of the harvester was approximate, $5 \mathrm{~km} / \mathrm{h}$.

2. For stalk diameters 3.12 and $3.76 \mathrm{~cm}$, row spacing 78.89 and $88.75 \mathrm{~cm}$, cutting height $0 \mathrm{~cm}$ with both 2 and 4 knives, the proper forward speed of the harvester was ranged from 4 to $4.5 \mathrm{~km} / \mathrm{h}$.

\section{Effect of row spacing:}

The distance between the rows is an important factor that plays a vital role, especially in estimating the field capacity of the machine in addition to the throughput capacity, as shown in table 1. Row spacing is one of the most important factors that affect stalk diameters. At row spacing $71 \mathrm{~cm}$, the average stalk diameter is $2.63 \mathrm{~cm}$, while at row spacing 78.89 and $88.75 \mathrm{~cm}$ average stalk diameter was 3.12 and $3.76 \mathrm{~cm}$ respectively, as shown in table 2 .

\section{Effect of cutting height:}

The cutting height is a very important factor, especially in estimating the power requirements and cutter head efficiency at different forward speed and row distance, as shown in table 2.

Three cutting height were used as follow; cutting at ground level, 2.00 and $4.00 \mathrm{~cm}$ to determine the power requirements and base cutter efficiency of harvesting sugar cane stalks from the ground level. The length of each test was $25 \mathrm{~m}$ and was repeated thrice.

The proposed fixed parameters to carry out these experiments were: forward speeds $=3,3.5$, 4.5 and $5 \mathrm{~km} / \mathrm{h}$, row spacing $=70,80$, and $90 \mathrm{~cm}$, stalk diameters $=2.5,3$, and $3.5 \mathrm{~cm}$ and No. of knives $=2$, and 4 , as shown in table 2 . 


\subsubsection{Effect of the number of knives:}

Two groups of knives were used as 2 and 4 knives to determine the power requirements and base cutter efficiency of harvesting sugar cane stalks from the ground level, as shown in table 3. The length of each test was $25 \mathrm{~m}$ and was repeated thrice.

The proposed fixed parameters to carry out these experiments were: forward speeds $=3,3.5$, 4.5 and $5 \mathrm{~km} / \mathrm{h}$, cutting heights $=0,2$, and $4 \mathrm{~cm}$, stalk diameters $=2.5,3$, and $3.5 \mathrm{~cm}$ and row spacing $=70,80$, and $90 \mathrm{~cm}$.

Table 1: Effect of inter-row spacs on machine performance. $\quad($ Cutting height $=$ ground level and No. of knives $=4$ )

\begin{tabular}{|l|c|c|c|c|c|c|c|c|c|c|c|c|}
\hline $\begin{array}{l}\text { Machine } \\
\text { performance }\end{array}$ & \multicolumn{3}{|c|}{ Filed (1) } & \multicolumn{3}{c|}{ Filed (2) } & \multicolumn{3}{c|}{ Filed (3) } \\
\hline Row spacing, cm & \multicolumn{3}{|c|}{71.00} & \multicolumn{3}{c|}{78.89} \\
\hline $\begin{array}{l}\text { Av. stalk diameter, } \\
\text { cm }\end{array}$ & \multicolumn{3}{|c|}{2.63} & \multicolumn{3}{c|}{3.12} & \multicolumn{3}{c|}{88.75} \\
\hline $\begin{array}{l}\text { Forward speed, } \\
\text { km/h }\end{array}$ & 2.86 & 3.75 & 4.38 & 5.13 & 2.84 & 3.72 & 4.47 & 5.08 & 2.92 & 3.69 & 4.28 & 5.10 \\
\hline $\begin{array}{l}\text { No. of uncutting } \\
\text { stalks }\end{array}$ & 0 & 0 & 0 & 0 & 0 & 0 & 0 & $\mathbf{N}^{*}$ & 0 & 0 & 0 & $\mathbf{N}^{*}$ \\
\hline $\begin{array}{l}\text { Cutter head } \\
\text { efficiency, \% }\end{array}$ & 100 & 100 & 100 & 100 & 100 & 100 & 100 & $\mathbf{N}^{*}$ & 100 & 100 & 100 & $\mathbf{N}^{*}$ \\
\hline Field capacity, Fed/h & 0.76 & 0.94 & 1.04 & 1.16 & 0.84 & 1.03 & 1.18 & $\mathbf{N}^{*}$ & 0.97 & 1.15 & 1.29 & $\mathbf{N}^{*}$ \\
\hline $\begin{array}{l}\text { Throughput } \\
\text { capacity, ton/h }\end{array}$ & 28.01 & 34.44 & 38.47 & 42.90 & 40.98 & 50.25 & 57.45 & $\mathbf{N}^{*}$ & 58.72 & 70.13 & 78.09 & $\mathbf{N}^{*}$ \\
\hline $\begin{array}{l}\text { Fuel consumption, } \\
\text { l/h }\end{array}$ & 8.92 & 10.51 & 11.66 & 13.06 & 10.35 & 12.39 & 14.21 & $\mathbf{N}^{*}$ & 11.45 & 13.50 & 15.11 & $\mathbf{N}^{*}$ \\
\hline $\begin{array}{l}\text { Total operating } \\
\text { costs, EGP/h }\end{array}$ & 93.1 & 99.8 & 104.6 & 110.5 & 99.1 & 107.7 & 115.3 & $\mathbf{N}^{*}$ & 103.7 & 112.4 & 119.1 & $\mathbf{N}^{*}$ \\
\hline $\begin{array}{l}\text { Total operating } \\
\text { costs, EGP/Fed }\end{array}$ & 122.5 & 106.8 & 100.2 & 94.9 & 117.9 & 104.5 & 97.9 & $\mathbf{N}^{*}$ & 107.3 & 97.4 & 92.7 & $\mathbf{N}^{*}$ \\
\hline $\begin{array}{l}\text { Power requirements, } \\
\text { kW }\end{array}$ & 27.31 & 32.19 & 35.70 & 39.99 & 31.69 & 37.92 & 43.50 & $\mathbf{N}^{*}$ & 35.04 & 41.33 & 46.27 & $\mathbf{N}^{*}$ \\
\hline $\begin{array}{l}\text { Knife rotational } \\
\text { speed, rpm }\end{array}$ & 707.4 & 942.8 & 1112.3 & 1319.1 & 702.9 & 932.4 & 1138.5 & $\mathbf{N}^{*}$ & 722.8 & 925.9 & 1085.1 & $\mathbf{N}^{*}$ \\
\hline $\begin{array}{l}\text { Knife linear speed, } \\
\text { m/s }\end{array}$ & 17.03 & 22.70 & 26.78 & 31.76 & 16.92 & 22.45 & 27.41 & $\mathbf{N}^{*}$ & 17.40 & 22.29 & 26.12 & $\mathbf{N}^{*}$ \\
\hline Speed ratio & 21.42 & 21.76 & 22.02 & 22.30 & 21.42 & 21.75 & 22.05 & $\mathbf{N}^{*}$ & 21.43 & 21.74 & 21.97 & $\mathbf{N}^{*}$ \\
\hline
\end{tabular}

Note: $\mathrm{N}^{*}=$ Tractor overloaded and stopped. 
Table 2: Effect of cutting height on machine performance. (row spacing $=88.75 \mathrm{~cm}$ and $\mathrm{No}$. of knives $=4$ )

\begin{tabular}{|c|c|c|c|c|c|c|c|c|c|c|c|c|}
\hline Machine performance & \multicolumn{12}{|c|}{ Filed (3) } \\
\hline Cutting height, cm & \multicolumn{4}{|c|}{ Ground-level } & \multicolumn{4}{|c|}{2.00} & \multicolumn{4}{|c|}{4.00} \\
\hline Av. stalk diameter, cm & \multicolumn{12}{|c|}{3.76} \\
\hline Forward speed, km/h & 2.92 & 3.69 & 4.28 & 5.10 & 2.97 & 3.66 & 4.32 & $\begin{array}{c}5.0 \\
0\end{array}$ & 2.93 & 3.70 & 4.46 & $\begin{array}{c}5.0 \\
1\end{array}$ \\
\hline No. of uncutting stalks & 0 & 0 & 0 & $\mathrm{~N}^{*}$ & 0 & 0 & 2 & $\mathrm{~N}^{*}$ & 0 & 1 & 2 & $\mathrm{~N}^{*}$ \\
\hline Cutter head efficiency, \% & 100 & 100 & 100 & $\mathrm{~N}^{*}$ & 100 & 100 & 98 & $\mathrm{~N}^{*}$ & 100 & 99 & 98 & $\mathrm{~N}^{*}$ \\
\hline Field capacity, Fed/h & 0.97 & 1.15 & 1.29 & $\mathrm{~N}^{*}$ & 0.98 & 1.15 & 1.29 & $\mathrm{~N}^{*}$ & 0.97 & 1.16 & 1.32 & $\mathrm{~N}^{*}$ \\
\hline $\begin{array}{l}\text { Throughput capacity, } \\
\text { ton/h }\end{array}$ & 58.72 & 70.13 & 78.09 & $\mathrm{~N}^{*}$ & 58.71 & 68.85 & 77.65 & $\mathrm{~N}^{*}$ & 57.51 & 68.60 & 78.49 & $\mathrm{~N}^{*}$ \\
\hline Fuel consumption, $\mathbf{l} / \mathbf{h}$ & 11.45 & 13.50 & 15.11 & $\mathrm{~N}^{*}$ & 11.56 & 13.41 & 15.12 & $\mathrm{~N}^{*}$ & 11.47 & 13.52 & 15.61 & $\mathrm{~N}^{*}$ \\
\hline $\begin{array}{l}\text { Total operating costs, } \\
\text { EGP/h }\end{array}$ & 103.7 & 112.4 & 119.1 & $\mathrm{~N}^{*}$ & 104.2 & 112.0 & 119.1 & $\mathrm{~N}^{*}$ & 103.8 & 112.4 & 121.2 & $N^{*}$ \\
\hline $\begin{array}{l}\text { Total operating costs, } \\
\text { EGP/Fed }\end{array}$ & 107.3 & 97.4 & 92.7 & $\mathrm{~N}^{*}$ & 106.6 & 97.7 & 92.2 & $\mathrm{~N}^{*}$ & 107.2 & 97.3 & 91.7 & $\mathrm{~N}^{*}$ \\
\hline Power requirements, kW & 35.04 & 41.33 & 46.27 & $\mathrm{~N}^{*}$ & 35.39 & 41.05 & 46.27 & $\mathrm{~N}^{*}$ & 35.12 & 41.38 & 47.77 & $\mathrm{~N}^{*}$ \\
\hline $\begin{array}{l}\text { Knife rotational speed, } \\
\text { rpm }\end{array}$ & 722.8 & 925.9 & 1085.1 & $\mathrm{~N}^{*}$ & 734.0 & 916.8 & 1085.3 & $\mathrm{~N}^{*}$ & 725.4 & 927.5 & 1133.7 & $N^{*}$ \\
\hline Knife linear speed, m/s & 17.40 & 22.29 & 26.12 & $\mathrm{~N}^{*}$ & 17.67 & 22.07 & 26.13 & $\mathrm{~N}^{*}$ & 17.46 & 22.33 & 27.29 & $\mathrm{~N}^{*}$ \\
\hline Speed ratio & 21.43 & 21.74 & 21.97 & $\mathrm{~N}^{*}$ & 21.44 & 21.72 & 21.79 & $\mathrm{~N}^{*}$ & 21.44 & 21.74 & 22.05 & $\mathrm{~N}^{*}$ \\
\hline
\end{tabular}

Note: $\mathrm{N}^{*}=$ Tractor overloaded and stopped.

Table 3: Effect of No. of knives on machine performance. (cutting height $=$ ground level and row spacing $=88.75 \mathrm{~cm}$ )

\begin{tabular}{|c|c|c|c|c|c|c|c|c|}
\hline Machine performance & \multicolumn{8}{|c|}{ Filed (3) } \\
\hline No. of knives & \multicolumn{4}{|c|}{2} & & \multicolumn{3}{|c|}{4} \\
\hline Av. stalk diameter, cm & \multicolumn{8}{|c|}{3.76} \\
\hline Forward speed, km/h & 3.03 & 3.78 & 4.35 & 5.05 & 2.92 & 3.69 & 4.28 & 5.10 \\
\hline No. of uncutting stalks & $\mathbf{0}$ & $\mathbf{0}$ & $\mathbf{0}$ & $\mathbf{N}^{*}$ & $\mathbf{0}$ & $\mathbf{0}$ & $\mathbf{0}$ & $\mathbf{N}^{*}$ \\
\hline Cutter head efficiency, $\%$ & 100 & 100 & 100 & $\mathrm{~N}^{*}$ & 100 & 100 & 100 & $\mathbf{N}^{*}$ \\
\hline Field capacity, Fed/h & 0.99 & 1.17 & 1.30 & $\mathbf{N}^{*}$ & 0.97 & 1.15 & 1.29 & $\mathbf{N}^{*}$ \\
\hline Throughput capacity, ton/h & 60.40 & 71.37 & 79.02 & $\mathbf{N}^{*}$ & 58.72 & 70.13 & 78.09 & $\mathbf{N}^{*}$ \\
\hline Fuel consumption, $1 / \mathrm{h}$ & 11.77 & 13.75 & 15.31 & $\mathbf{N}^{*}$ & 11.45 & 13.50 & 15.11 & $\mathbf{N}^{*}$ \\
\hline Total operating costs, EGP/h & 105.1 & 113.4 & 120.0 & $\mathbf{N}^{*}$ & 103.7 & $\mathbf{1 1 2 . 4}$ & 119.1 & $\mathbf{N}^{*}$ \\
\hline Total operating costs, EGP/Fed & 105.7 & 96.5 & 92.3 & $\mathbf{N}^{*}$ & 107.3 & 97.4 & 92.7 & $\mathbf{N}^{*}$ \\
\hline Power requirements, $\mathrm{kW}$ & 36.03 & 42.08 & 46.88 & $\mathbf{N}^{*}$ & 35.04 & 41.33 & 46.27 & $\mathbf{N}^{*}$ \\
\hline Knife rotational speed, rpm & 754.8 & 950.0 & 1104.9 & $\mathbf{N}^{*}$ & 722.8 & 925.9 & 1085.1 & $\mathbf{N}^{*}$ \\
\hline Knife linear speed, $\mathrm{m} / \mathrm{s}$ & 18.17 & 22.87 & 26.60 & $\mathrm{~N}^{*}$ & $\mathbf{1 7 . 4 0}$ & 22.29 & 26.12 & $\mathbf{N}^{*}$ \\
\hline Speed ratio & 21.58 & 21.78 & 22.00 & $\mathbf{N}^{*}$ & 21.43 & 21.74 & 21.97 & $\mathbf{N}^{*}$ \\
\hline
\end{tabular}

Note: $\mathrm{N}^{*}=$ Tractor overloaded and stopped. 


\section{SUMMARY AND CONCLUSION}

It was, therefore, necessary to pay full attention to sugary crops, especially sugar cane, to increase productivity and to bridge the gap between production and consumption by increasing the productivity of sugarcane. The main problem of sugar cane plantation is the harvesting process. The sugarcane harvesting season lasts for 5 months in Egypt, starting in December and ending in May.

It can be concluded that the best operating conditions for harvesting sugar cane stalks to obtain the maximum machine performance are:

1. At row spacing $=88.75 \mathrm{~cm}$, stalk diameter $=3.76 \mathrm{~cm}$ and cutting height at ground level the proper machine forward speed $=4.5 \mathrm{~km} / \mathrm{h}$, knives rotational speed $=1104.9 \mathrm{rpm}$, power requirements $=46.88 \mathrm{~kW}$ and field capacity $=1.3 \mathrm{Fed} / \mathrm{h}$

2. At row spacing $=78.89 \mathrm{~cm}$, stalk diameter $=3.12 \mathrm{~cm}$ and cutting height at ground level the proper machine forward speed $=4.5 \mathrm{~km} / \mathrm{h}$, knives rotational speed $=1111.9 \mathrm{rpm}$, power requirements $=42.78 \mathrm{~kW}$ and field capacity $=1.16 \mathrm{Fed} / \mathrm{h}$

3. At row spacing $=71 \mathrm{~cm}$, stalk diameter $=2.63 \mathrm{~cm}$ and cutting height at ground level the proper machine forward speed $=5 \mathrm{~km} / \mathrm{h}$, knives rotational speed $=1100.3 \mathrm{rpm}$, power requirements $=39.73 \mathrm{~kW}$ and field capacity $=1.16 \mathrm{Fed} / \mathrm{h}$.

\section{REFERENCES}

Abd-El Mawla, H. A., et al. (2014). "Field evaluation and crop conditions related to sugar cane mechanical harvesting”, Egypt. J. Agric. Res., 92(1), 257: 271.

Bastian J. and Shridar, B. (2014). "Investigation on Mechanical Properties of Sugarcane Stalks for the Development of a Whole Cane Combine Harvester", Indian journal of applied research, 4 (9), pp. 1-9.

Debeer, A. G. (1974). "An assessment of the options for mechanical harvesting of sugarcane in South Africa", Proceedings of the South African Sugar Technologists' Association, pp. 111-112.

Hamada, Y. M. (2011). "Water Resources Reallocation in Upper and Middle Egypt", EWRA European Water, EW Publications, 33: 33-44.

Rohit J. M., et al. (2015). "Design and Fabrication of Small Scale Sugarcane Harvester", Journal of Mechanical and Civil Engineering, 2(3): 1 - 9. O

Siddaling, S. and Ravaikiran, B. S. (2015). "Design and Fabrication of Small Scale Sugarcane Harvesting Machine”, International Journal of Engineering Research and General Science, 3(4), pp. 293-298. 


\section{تصنيع واختبار آله ذات صفين لحصاد القصب معلقه أماميا على الجرار}

أ.د/ عبد الله مسعد زين الدين' ، أ.د/ سعد فتح الله أحمد'، د/وليد محمد حنفي و م/ عبد الله الثوادفي الوكيلّ

' استاذ الهندسة الزر اعية ـ كلية الزر اعة ـ جامعة الاسكندرية ـ الاسكندرية ـ الثاطبي - مصر.

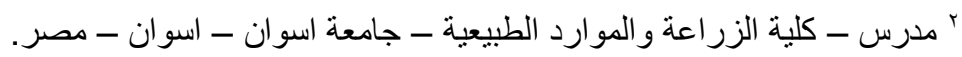

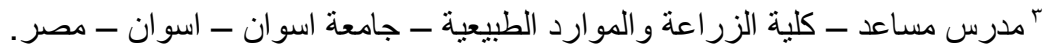

الملخص العربى

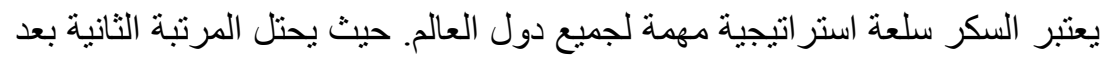

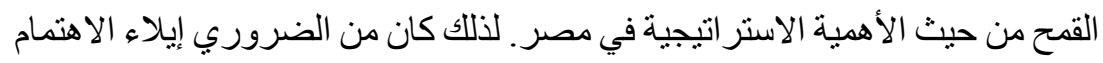

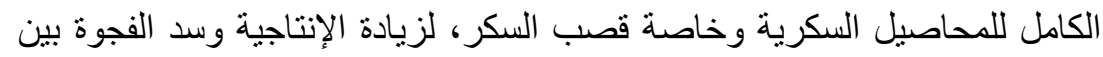

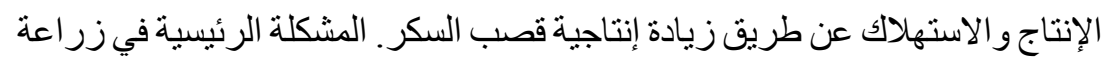

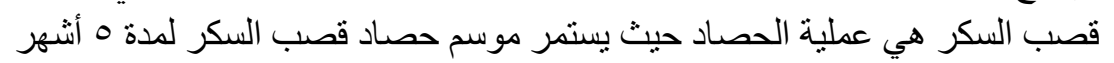

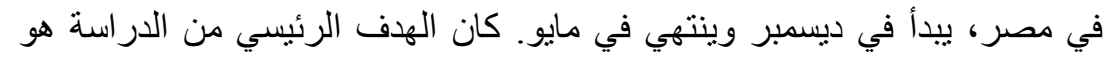

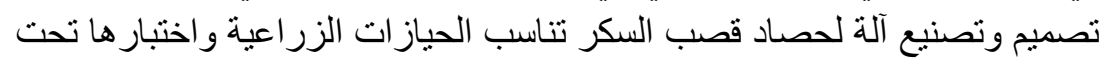

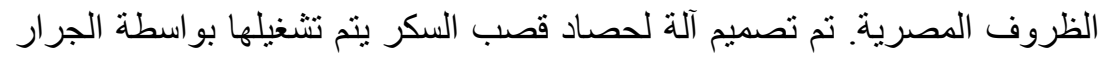

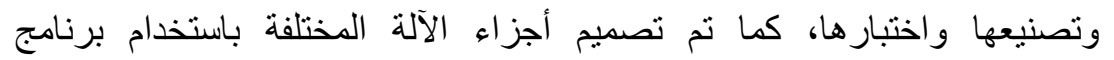
"SolidWorks"

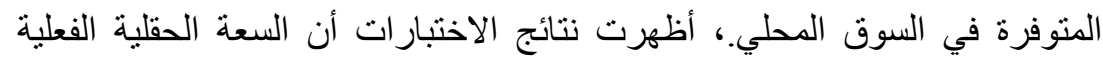

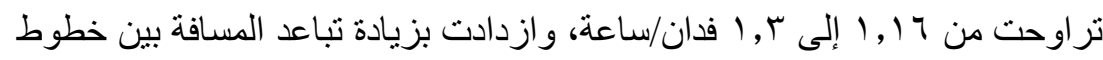
الزر اعة و السر عة الأمامية. في الحقول ذات كثافة المحاصيل العالية، بلغ منوسط كفاءة العباء

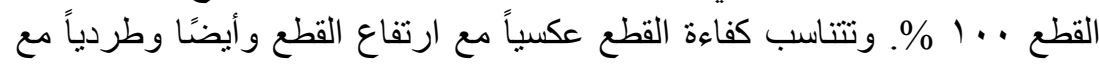

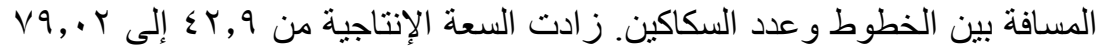

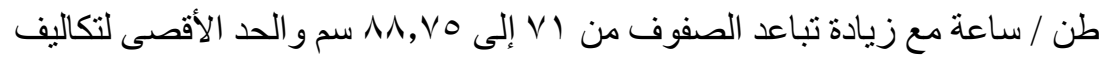

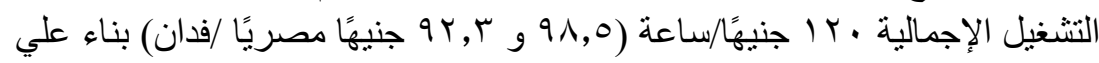

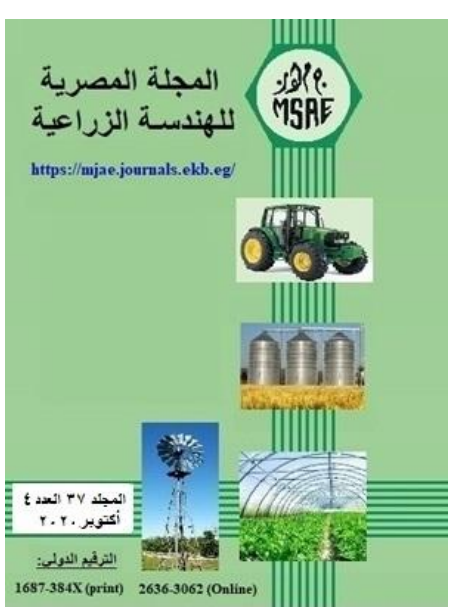

C المجلة المصرية للهندسة الزراعية

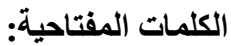
أنظمة حصاد قصب السكرة، النظم المميكنة، آلة حصاد قصب النبة السكر الجامعة، آلات القطع المعلقة على آلى البكر الجرار القدرة اللازمة للقطع. 